\title{
Vegetable Insect Control with Minimal Use of Insecticides
}

\author{
John T. Trumble \\ Department of Entomology, University of California, Riverside, CA 92521
}

\section{RATIONALE FOR MINIMUM INSECTICIDE VEGETABLE PRODUCTION}

Large scale commercial vegetable producers rarely adopt minimum input or sustainable agricultural practices for altruistic reasons. While some family-owned concerns have followed this approach with the intent of passing their land onto the next generation in as pristine a state as possible, much of California's vegetable hectarage is managed by large corporations. Thus, development and implementation strategies using reduced pesticide input are less likely the result of environmental concerns and more likely due to economic incentives, legislation limiting pesticide use, or the development of significant levels of pesticide resistance.

In terms of pesticide use, the California vegetable industry is approaching a critical period. California's expanding urban population has led to an increase in the influence of environmental activists, labor unions, and other consumer groups that are increasingly vocal in their opposition to pesticides. In addition, the current senate and assembly, committees in California that deal with pesticides have few members with rural or agricultural backgrounds.

This situation has lead to an increase in legislation restricting pesticides. At least 26 new bills relevant to the subject were introduced in California in 1987 alone. Nearly all of these would require further restrictions on the use of chemicals for insect control. The impact of the new laws dealing with ground water contamination -and plant-back restrictions has dramatically changed pesticide use patterns in California; as a consequence, the application of persistent pesticides has declined appreciably. The impact of laws generated by referendum (placed on the ballot after proponents file the required number of signatures on petitions) is less well-defined. Such consumer-generated legislation provides evidence of the growing perception that consumers take the risk when pesticides are used, while growers reap the profits.

There also has been a resurgence in environmental concern by the general population. In the past few years, incidents of environmental concern at Love Canal and Kesterson Reservoir, as well as the tragic events at Bhopal, India, have been given considerable time on television. The publicity associated with the watermelon contamination incident in California and the recent National Academy of Sciences report (National Research Council, 1986) highlighting the potential for pesticidal contamination in vegetables, have brought this concern into nearly every household in the country. Our ability to find residues at the parts-per-trillion level has aggravated this problem. Many consumers do not recognize differences in risk levels between parts per hundred and parts per trillion, they only recognize that no level of risk is acceptable.

An additional stimulus for reduced insecticide use is the declining availability of efficacious insecticides. The rate of development of insecticide resistance is increasing exponentially (Georghiou, 1986). Nearly every entomologist study vegetable crop production can cite cases of extensive losses resulting from insecticide resistance. The \$20 million loss documented by California's celery industry in 1984 following the development of resistance by the leafminer [Liriomyza trifolii (Burgess) (Diptera: Agromyzidae)] to diverse chemicals provides an excellent example (California Celery Research Advisory Board, 1986). Thus, the need has been adequately demonstrated to the vegetable industry that a more-prudent approach would include a move toward less insecticide-intensive pest management practices.

\section{The search for new approaches}

Several new or rediscovered approaches to low insecticide input agriculture are being investigated. One approach receiving considerable attention is the use of new technology machinery. Electrostatic sprayers and controlled-droplet application devices offer help in reducing amounts of insecticides used in vegetable crop systems (Matthews, 1979), but, by themselves, will not provide a long-term solution to insecticide resistance. The recent development of a tractor-mounted suction unit that provides excellent control of Lygus spp. in strawberries (E. Show, Driscoll Corp., personal communication) offers considerable advantages over insecticide applications that cause resurgence in two-spotted spider mite populations (Tetranychus urticae Koch).

Many of the "new" techniques suggested for sustainable agriculture are simply improvements or recycling of approaches developed for integrated pest management (IPM) purposes. This recycling does not make these approaches less useful; in fact the sustained interest is helping to increase use. Moreover, IPM practices have become a mainstay for implementation of sustainable agriculture (Poincelot, 1986). Examples include use of polyester row covers for insect exclusion (Natwick and Durazo, 1985), the pheromone confusion technique (Baker et al., 1988), classical breeding or genetic engineering of insect-resistant plant cultivars (Trumble and Quiros, 1988), strip cropping or rotation (Power, 1988), intercropping (Letourneau, 1987), or improvement of "biorational" pesticides such as Bacillus thuringiensis through isolate selection or genetic engineering. Also under consideration are the concepts of managing pesticide resistance in vegetable crop systems through rotational programs that benefit the natural biological control agents and the use of new techniques for monitoring insecticide resistance levels in the field (Trumble, 1985; Sanderson et al., 1989). Probably the most striking development in the past few years is the degree to which these approaches are being integrated into management practices at the large-scale commercial production level.

\section{THE EXAMPLE OF CELERY}

Celery is an important agricultural commodity in California, with annual returns exceeding \$145 million on 8500 ha (California Celery Research Advisory Board, 1986). During the mid-to late 1970s, introduction of the phytophagous agromyzid, L. trifolii, began causing substantial economic losses (Trumble, 1981). In response to the loss of efficacy of many agricultural chemicals for leafminer control (Leibee, 1981), and the potential for rapid development of insecticide resistance (Keil and Parrella, 1983), interest increased in the development of a biological control or resistance management program that would maximize pest suppression while minimizing insecticide input.

The appeal of such a program was enhanced by reports that many insecticides were generating outbreaks of Liriomyza species. Hills and Taylor (1951) first documented this problem with reports that Liriomyza species populations [probably L. sativae (Blanchard)] 
increased and parasite populations decreased following DDT application. Similar results were reported by Wene (1955) for methoxychlor, dieldrin, endrin, and lindane, and by Getzin (1960) for parathion, ethion, and diazinon. More recently, these effects have been documented for permethrin (Poe et al., 1978), methomyl (Oatman and Kennedy, 1976; Johnson et al., 1980; Trumble and Toscano, 1983), and a variety of other compounds (Pohronezny et al., 1978; Lange et al., 1980). Therefore, the studies reported here were an effort to: a) reduce the dependency of the celery industry in California on scheduled insecticide applications, b) increase the use of biological control agents for L. trifolii, and c) attempt to manage the increasing problems of insecticide resistance.

\section{Development of a sustainable approach to insect control}

Population assessment and the potential for biological control. Initially two goals were established. First, a reliable sampling plan for estimating, field populations of L trifolii and related parasites was required. Second, we wished to document the key parasitoid species attacking the leafminer and determine their potential for providing significant levels of leafminer suppression in untreated systems.

Leafminer populations were adequately estimated by the leaf subsample technique throughout the growing season (Trumble and Nakakihara, 1983). Coefficients of variation were usually < $25 \%$ for weekly means. The agreement between immediate visual examination of the leaves for percent parasitism and the ratio of emergent leafminers to parasites was high. Thus, rather than waiting 4 weeks for an estimate of percent parasitism, scouts with access to a dissecting microscope could estimate the levels of parasitism immediately.

Liriomyza trifolii was the dominant leafminer species in celery (> 95\%), although L sativae were present (Fig. 1). Populations of

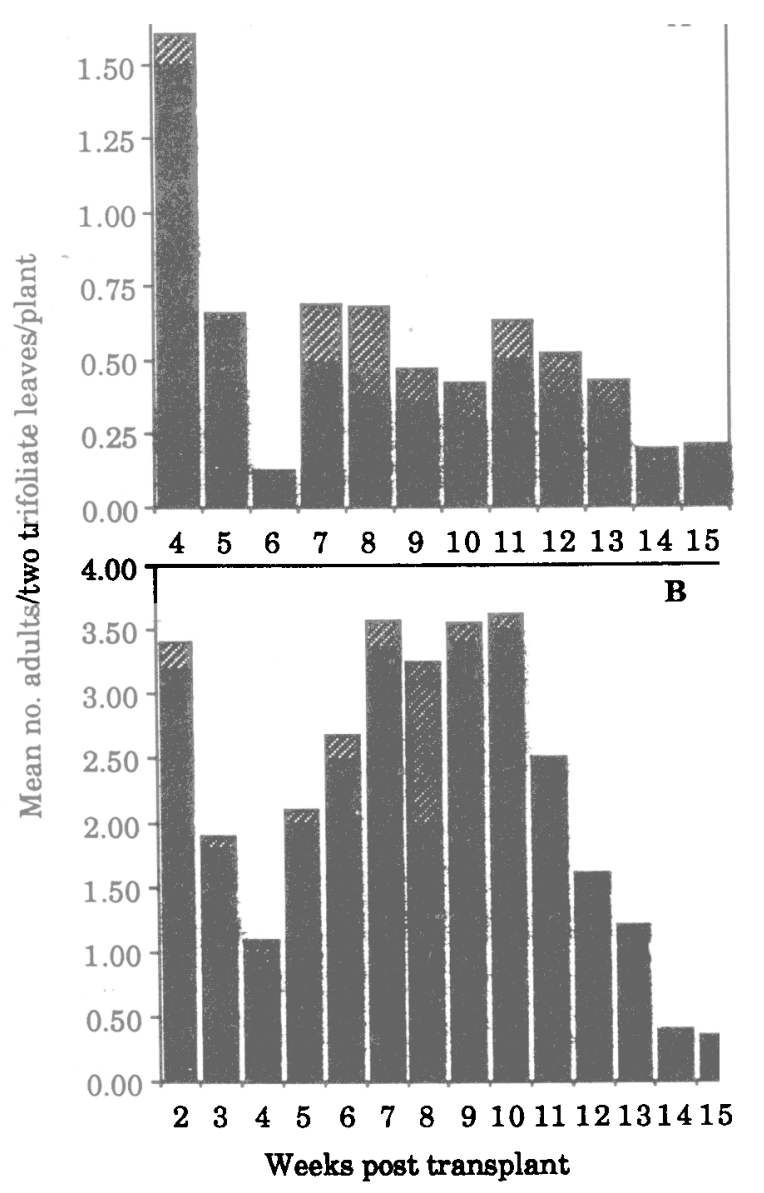

Fig. 1. Occurrence of Liriomyza trifolii (solid black) and L sativae (shaded) in non-outbreak (A) and outbreak years (B). Numbers based on one upper and one lower trifoliate per plant for 50 plants per week.
Liriomyza species increased $>100 \%$ in the 2nd year, probably in response to a warm winter and infestations in greenhouse-grown transplants. Peak populations of $L$. sativae corresponded with the removal of nearby tomato plantings, demonstrating the intercrop migration problems common to L. sativae and L. trifolii (Zehnder and Trumble, 1984). In both years, populations started at relatively high levels, dropped by $50 \%$ or more, and then rebounded for 7 to 8 weeks before a decline at the end of the season.

The parasitoids reared from leafminers in celery during both years included species in the families Eulophidae: Diglyphus spp. $(69 \%$ of total parasitoids), Chrysonotornyia punctiventris (Crawford) (16\%), Chrysocharis parski Crawford (9.1\%), Chrysocharis ainsliei Crawford (1\%); Pteromalidae: Halticoptera circulus (Walker) (40\%) and Braconidae: Opius spp. (> 1\%). The cyclical occurrence of parasitism in both years explains the leafminer population fluctuations (Fig. 2). The high initial populations of leafminers declined in response to an increase in naturally occurring parasitism (and possibly host feeding) and then recovered. As the crop neared harvest, the percent parasitization increased to $>84 \%$ in both years. This level of suppression before harvest clearly would help reduce the problems associated with intercrop migration following harvest. However, although the parasitoids were affecting the population dynamics of leafminers, information on the economic threshold for leafminer damage in celery was required before the utility of the parasitoids as a control measure could be determined.

Documenting injury threshold levels. Both laboratory and fieldoriented approaches were used to provide critical information on the economic impact of L. trifolii on celery (Trumble et al., 1985). In laboratory studies, a dual-isotope porometer (Johnson et al., 1979) was used to measure rates of photosynthesis, transpiration, mesophyll conductance, and stomatal conductance for celery plants subjected to various levels of leafminer damage. The gas exchange equations used to calculate the physiological characteristics and associated definitions were as follows:

Photosynthesis in $\mathrm{mg} \mathrm{CO}$ per unit of area/time $=\mathrm{CO}_{2} /\left(\mathrm{R}_{\mathrm{S}}+\right.$ $\mathrm{R}_{\mathrm{m}}$ ) and transpiration in $\mathrm{g} \mathrm{H}_{2} \mathrm{O}$ per unit of area/time $=\mathrm{H}_{2} \mathrm{O} / \mathrm{R}_{\mathrm{s}}$, where $\mathrm{CO}_{2}=$ the difference in concentration of carbon dioxide between the atmosphere and the leaf surface, $\mathrm{H}_{2} \mathrm{O}=$ the difference in water concentration between the leaf and the atmosphere, $\mathrm{R}_{\mathrm{s}}=$ the stomatal resistance to $\mathrm{H}_{2} \mathrm{O}$ or $\mathrm{CO}_{2}$ in $\mathrm{cm} \cdot \mathrm{s}^{-1}$, and $\mathrm{R}_{\mathrm{m}}=$ the resistance of the mesophyll to assimilation of $\mathrm{CO}_{2}$ in $\mathrm{cm} \cdot \mathrm{s}^{-1}$.

In laboratory studies with the dual-isotope porometer, a single leafminer per leaflet significantly reduced photosynthesis by $43 \%$, stomatal conductance by $36 \%$, mesophyll conductance by $21 \%$, and

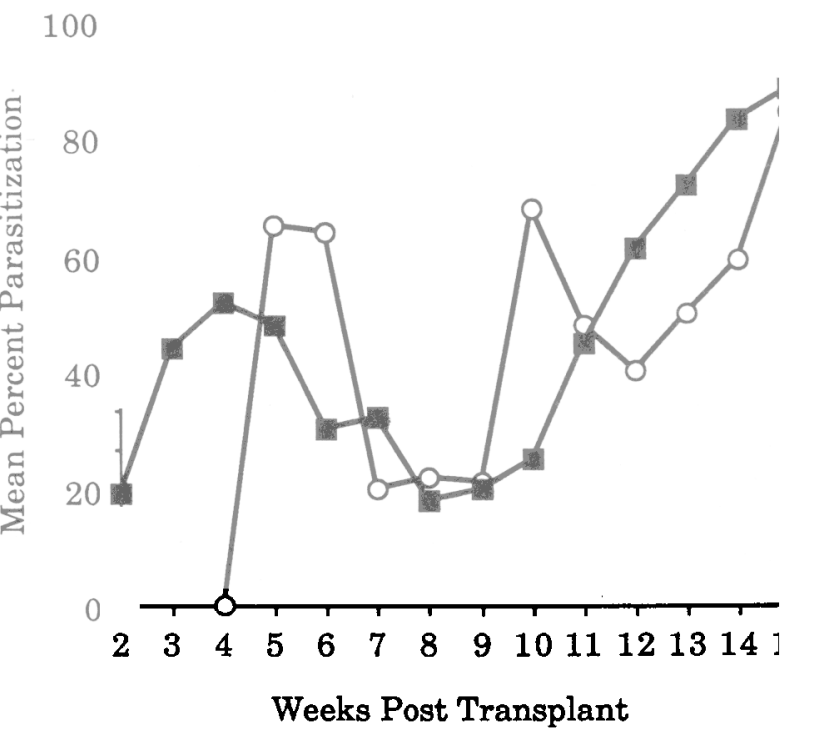

Fig. 2. Mean percent parasitism of Liriomyza spp. in outbreak (solid squares) and non-outbreak years (open circles). Note that the cycles of increases and decreases in parasitism are inversely proportional to the leafminer population levels seen in Fig. 1, regardless of the density of the leafminers. 
transpiration by $36 \%$ (Trumble et al., 1985). These results are in agreement with those of Johnson et al. (1983), where L. sativae caused similar reductions of photosynthetic activity on tomatoes. Although a reduction in photosynthesis of $>40 \%$ may be overestimating the productivity loss to the leaf because all leaf area was not distal to the mine, the nearly total loss of photosynthesis in the mined area $(\approx 1 / 10$ th of the leaf surface area) and the frequent occurrence of more than a single mine per leaf under field conditions may result in much greater physiological effects in commercial operations.

Various plant growth characteristics were monitored weekly in field tests for two sizes of celery transplants exposed to high and low levels of leafminer damage and two irrigation practices (drip and furrow). Populations of L. trifolii were manipulated in the field with weekly pesticide applications: methamidophos at $1.1 \mathrm{~kg}$ a.i./ ha minimized leafminer density and methomyl at $1.0 \mathrm{~kg}$ a.i./ha

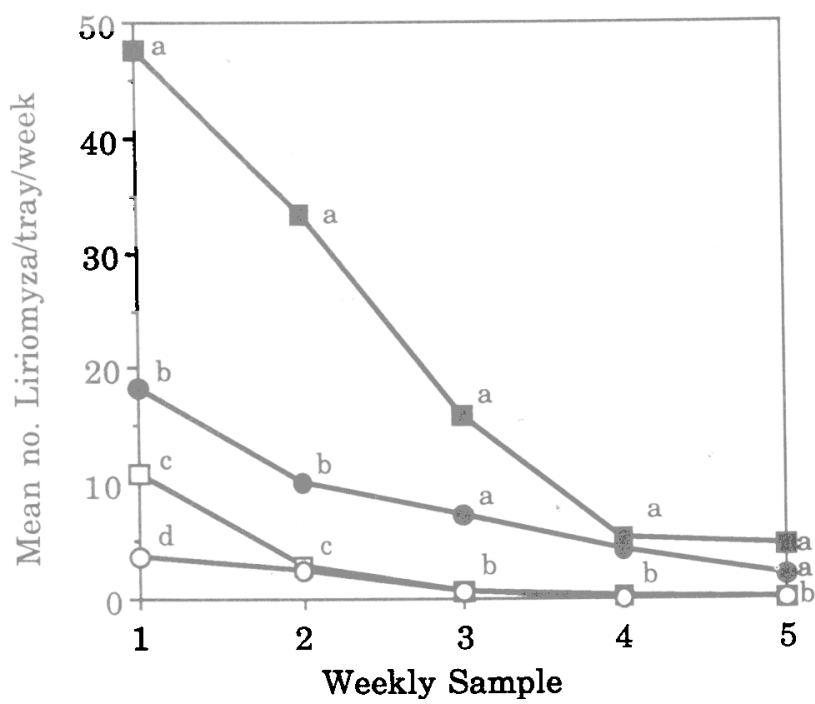

Fig. 3. Insecticide application and transplant size effects on densiy of Liriomyza spp. in celery. Values are based on four trays per replicate-and four replicates per treatment on each date. Means within a date followed by the same letter arc not significantly different at $P<0.05$ (Duncan's new multiple range test). Open squares $=$ methamidophos-treated small transplants, open circles = methamidophos-treated large transplants, closed squares $=$ methomyl-treated small transplants, and closed squares = methomyl-treated large transplants. maximized populations

Liriomyza species populations were significantly higher on methomyl-treated plants than on celery treated with methamidophos (Fig. 3 ). The size of the transplants also had an impact on the number of leafminers present: smaller plants had higher populations on two of the five sampling dates. These differences in leafminer population densities significantly $(P<0.05)$ affected plant height and number of petioles within the first 11 weeks of plant growth (Table 1). At harvest, 16 weeks after transplanting, only the large plants protected from leafminers with methamidophos had reached marketable size. The large plants treated with methomyl reached equivalent size 3 weeks later. The smaller transplants required 3 to 6 additional weeks, depending on whether leafminer populations were controlled by methamidophos or exacerbated by methornyl, respectively.

Such reductions in plant growth have serious economic repercussions for growers in California. To reduce the effects of an insect-borne virus, California growers have established a celeryfree period. Nearly all growers plant immediately following this period, and normally have just enough time to market the crop for the Thanksgiving-Christmas holiday period. However, the extension of the growing period for an additional 3 or more weeks by a moderate infestation may cause this lucrative marketing period to be missed. Crop values often drop by $30 \%$ to $50 \%$ following these holidays. Thus, potential losses in market value, as well as the extra irrigation, pesticide, and labor costs associated with the maintenance of the planting for an additional 3 or more weeks, can result in substantial economic losses. Examination of these results, along with the previous measurements of mines per plant and the effect of leafmines on photosynthetic criteria, allowed the estimation of an injury threshold for leafminers of $25 \%$ of the leaves per plant with active mines.

Using this threshold for damage, it became apparent that the beneficial insects alone would not provide an adequate level of leafminer suppression throughout the crop season. Unfortunately, no differences were seen in leafminer population levels between drip- vs. furrow-irrigated celery. We had hoped that the additional moisture between the plant rows on a bed would favor development of pathological agents capable of controlling the pupal stage, which occurs on or just beneath the soil surface. When coupled with the undesirable effect of using the smaller transplants, the most readily implemented cultural control techniques appeared ineffective. Thus, the next option was to attempt to develop an integrated program that would minimize the need for insecticides while taking full advantage of the population suppression offered by the parasitoids.

Table 1. Mean number of petioles and height per plant for small and large transplants with methomyl and methamidophos ${ }^{2}$.

\begin{tabular}{|c|c|c|c|c|}
\hline \multirow{3}{*}{$\begin{array}{l}\text { Weeks post- } \\
\text { transplant }\end{array}$} & \multicolumn{2}{|c|}{ Methomyl } & \multicolumn{2}{|c|}{ Methomidophos } \\
\hline & \multicolumn{2}{|c|}{ Transplant size } & \multicolumn{2}{|c|}{ Transplant size } \\
\hline & Small & Large & Small & Large \\
\hline \multicolumn{5}{|c|}{ Mean number of petioles per plant } \\
\hline 4 & $3.2 \mathrm{~b}$ & $4.1 \mathrm{a}$ & $3.2 \mathrm{~b}$ & $4.1 \mathrm{a}$ \\
\hline 5 & $\ldots$ & $\cdots$ & $\ldots$ & -.- \\
\hline 6 & $3.9 \mathrm{c}$ & $6.6 \mathrm{~b}$ & $3.5 \mathrm{~b}$ & $8.2 \mathrm{a}$ \\
\hline 7 & $4.5 \mathrm{c}$ & $9.3 \mathrm{~b}$ & $5.7 \mathrm{~b}$ & $12.8 \mathrm{a}$ \\
\hline 8 & $6.1 \mathrm{c}$ & $9.2 \mathrm{~b}$ & $8.6 \mathrm{~b}$ & $17.0 \mathrm{a}$ \\
\hline 9 & $7.4 \mathrm{c}$ & $15.5 \mathrm{~b}$ & $9.7 \mathrm{c}$ & $23.7 \mathrm{a}$ \\
\hline 10 & $14.2 \mathrm{c}$ & $22.1 \mathrm{~b}$ & $18.0 \mathrm{~b}$ & $29.4 \mathrm{a}$ \\
\hline 11 & $16.6 \mathrm{c}$ & $22.6 \mathrm{~b}$ & $22.0 \mathrm{~b}$ & $28.2 \mathrm{a}$ \\
\hline \multicolumn{5}{|c|}{ Mean plant height $(\mathrm{cm})$} \\
\hline 4 & $4.0 \mathrm{~b}$ & $14.8 \mathrm{a}$ & $3.9 \mathrm{~b}$ & $15.1 \mathrm{a}$ \\
\hline 5 & $4.1 \mathrm{~b}$ & $16.2 \mathrm{a}$ & $4.0 \mathrm{~b}$ & $14.7 \mathrm{a}$ \\
\hline 6 & $4.2 \mathrm{~b}$ & $16.1 \mathrm{a}$ & $5.0 \mathrm{~b}$ & $16.3 \mathrm{a}$ \\
\hline 7 & $4.9 \mathrm{~b}$ & $17.0 \mathrm{a}$ & $6.1 \mathrm{~b}$ & $21.2 \mathrm{a}$ \\
\hline 8 & $8.7 \mathrm{c}$ & $22.0 \mathrm{~b}$ & $10.5 \mathrm{c}$ & $29.9 \mathrm{a}$ \\
\hline 9 & $13.5 \mathrm{~b}$ & $35.0 \mathrm{a}$ & $14.1 \mathrm{~b}$ & $39.0 \mathrm{a}$ \\
\hline 10 & $18.1 \mathrm{~d}$ & $41.1 \mathrm{~b}$ & $22.1 \mathrm{c}$ & $47.2 \mathrm{a}$ \\
\hline 11 & $23.0 \mathrm{~d}$ & $50.1 \mathrm{~b}$ & $31.3 \mathrm{c}$ & $56.3 \mathrm{a}$ \\
\hline
\end{tabular}

${ }^{2}$ Five plants per replicate per sampling date; means within columns within categories followed by the same letter arc not significantly different $(P<0.05$, Duncan's new multiple range test). 
Integrating biological and chemical approaches. The primary goals of these studies were to examine the impact of registered and unregistered insecticides on the leafminer/parasite system and to establish whether a program that would minimize the development of pesticide resistance could be developed (Trumble and Toscano, 1983; Trumble, 1985). Four chemicals were evaluated: cyromazine, a growth inhibitor; avermectin $b_{1}$, an inhibitor of the gamma amino butyric acid system responsible for nerve to muscle transmission; methamidophos, an organophosphate insecticide acting as an acetylcholinesterase inhibitor; and methomyl, a carbamate acetylcholinesterase inhibitor that is widely used in celery production.

As seen in other studies, application of methomyl increased leafminer populations compared to other treatments and controls (Trumble and Toseano, 1983; Trumble, 1985). Adult parasite mortality was much higher in methomyl treatments, suggesting that Liriomyza spp. outbreaks were, in part, occurring in response to a release from biological control. None of the other insecticides significantly affected adult parasite mortality.

Larval parasites were negatively impacted by cyromazine and methamidophos. Both compounds reduced the total percentage of parasitism as compared to the control or the avermectin $b_{1}$ treatments.

Based on these data, an integrated pest and resistance management program was developed using a rotation of these pesticides. First, cyromazine could be applied to celery outside the greenhouse and for the first few weeks after transplanting. Usually, only the leafminer eggs and first-stage larvae are present at this time, neither of which serve as hosts of the parasitoids. Since the adult parasitoids are not affected by cyromazine, leafminers that escape insecticidal control would be subject to parasitization. Methamidophos could then be used until about 6 weeks post-transplanting. Because this compound has some negative effects on parasitoid survival, use should be limited. However, inclusion of this chemical would benefit resistance management as leafminer populations appear to revert to susceptibility to methamidophos when not exposed for a period of 3 months. Finally, avermectin $b_{1}$ could be used for leafminer suppression for the remaining 10 or more weeks of the crop. This insecticide would allow parasitoid populations to have maximum impact on the leafminers.

All of these chemicals should be used on an "as-needed" basis determined by an aggressive sampling program using the injury threshold level, Several studies have indicated that styrofoam trays may provide a rapid and effective means of monitoring leafminer populations (Trumble et al., 1985; Zehnder and Trumble, 1985). Because the key parasitoid species in California kill the larvae before they emerge and drop to the ground to pupate, the trays can be used to provide information on the relative efficiency of the parasitoids: if numbers of leafminers per plant are increasing, but pupae are not being captured in the trays, then the biological control agents are responding and no treatment will be necessary.

\section{Validation and economic evaluation of the low pesticide input approach}

Experimental 0.4-ha plantings of 5270-R celery were established at the Univ. of California's South Coast Field Station in Orange County during Fall 1987. Two treatments were evaluated in a randomized complete block design: a grower's standard approach using preventive treatments $(1.1 \mathrm{~kg}$ a.i. of methomyl and/or $0.22 \mathrm{~kg}$ a.i. permethrin/ha), and a second treatment consisting of the low insecticide input approach (Bacillus thuringiensis at 17,920 Spodoptera units/ha, avermectin $\mathrm{b}_{1}$ at $0.011 \mathrm{~kg}$ a.i./ha, and methamidophos at $1.0 \mathrm{~kg}$ a.i./ha).

Determination of the need for pesticide applications was based on weekly sampling. Effects of pesticides on L. trifolii and parasitoid populations were monitored using pupal trays described earlier. Beet armyworm populations [Spodoptera exigua (Hübner)] were monitored by weekly counts of 10 plants per replicate.

Economic data on costs of applications were collected from several sources, including pesticide distributors, farm advisors, and extension publications (Reed and Horel, 1979). Most growers currently employ scouts (generally for disease monitoring, but also some insect evaluation), so the costs of scouting would not be much different among the programs.

Numbers of pesticide applications were reduced from nine in the "standard" program (two insecticides per application) to five in the low-input approach (one insecticide per application). This change had a significant effect on the Liriomyza populations (Fig. 4). The injury threshold levels $(15+$ pupae per tray) were exceeded on three sampling dates in the grower standard program, and on no sampling dates in the low input approach. Thus, the low-input approach was effective in reducing the leafminer population below economic levels with fewer pesticide applications. However, it is apparent that fewer insecticide applications for leafminers could have been applied in the low-input system as the rotational program was followed, but the injury threshold was not reached. If leafminer-resistant celery cultivars developed for research purposes can be produced commercially (Trumble and Quiros, 1988), and if these cultivars do not have their resistance based on content of the carcinogenic and mutagenic linear furanocoumarins, pesticide applications probably will be reduced well below the current levels in the low-input approach.

Unfortunately, the S. exigua populations damaged $12 \%$ of the celery in the low-input approach compared to only $2 \%$ in the grower standard approach. This impact on crop value has been included in the analyses of economic return using both high- and low-input systems. An additional application of $B$. thuringiensis probably would have been cost-effective. As more effective strains of $B$. thuringiensis for S. exigua suppression are identified and commercialized, rates and applications may be reduced (Moar et al., 1986; Moar and Trumble, 1987). The development of analogs of avermectin $b$ that show 1500 times more activity on S. exigua also offer considerable promise for incorporation into a low-insecticide-input system (Trumble et al., 1987). Currently, insecticides registered for $S$. exigua suppression on celery (e.g., permethrin, methomyl) cause substantial mortality in leafminer parasite populations. Thus, development of new control approaches for S. exigua, including biorational insecticides or chemicals with low mammalian toxicity, is critically important to this system.

Determining the economic impact of these results required information on the market value of the crop at the time of harvest. The net gain from either strategy can be calculated by subtracting the cost of pest control from the value of the crop. As market value increases from $\$ 7$ to $\$ 13$ per carton, the relative advantage of using the low-input approach decreased from a high of nearly $\$ 321 /$ ha (difference between low- and high-input net gains) to a low of $\$ 222$ /

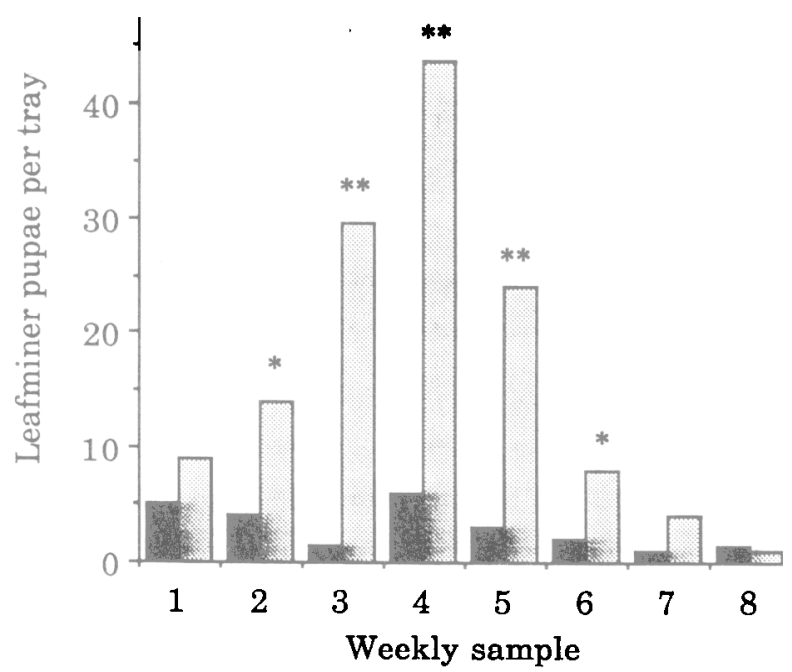

Fig. 4. Comparison of Liriomyza spp. populations in grower's "standard" program (shaded bars) vs. the low-insecticide-input approach (solid black bar;). Asterisks indicate significant differences at $P<0.05(*)$ or $P<$ $0.01(* *)$, t-test. Values based on four trays per replicate and four replicates per treatment on each date. 


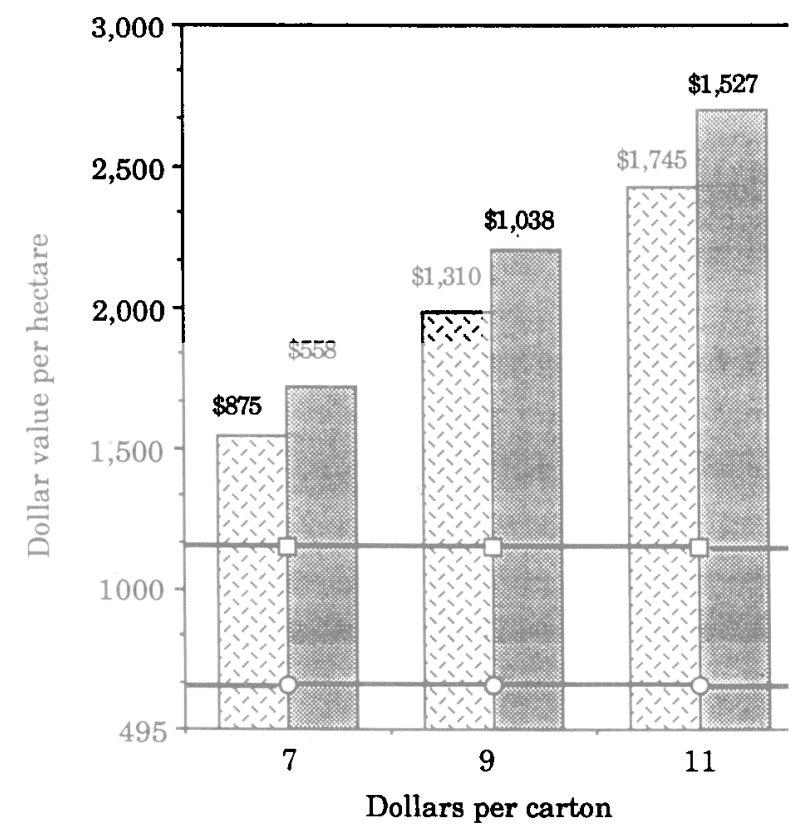

Fig. 5. Cost-benefit analyses of the grower's "standard" program vs. the low-pesticide-input approach for typical market values. Numbers above bars indicate the net gain (value at harvest minus cost of pest control). The value of the low input crop is represented by the crosshatched bars; the value of the standard input crop is represented by the shaded bars. The cost per hectare of the low-input approach is designated by the line with open circles, while the cost per hectare of the standard program is designated by the open squares.

ha over the grower standard approach (Fig. 5). However, these values actually" are conservative, and the differential between lowand high-input approaches could reasonably be expected to be higher. Costs and potential market value losses of an estimated 3 weeks of growing time needed to achieve the same size class at harvest in the standard program when compared to the low input program were not included. In addition, costs associated with increased soil compaction (due to additional trips through the field) in the grower's standard treatment were not incorporated in the economic analyses.

Benefits of the low-insecticide-input approach extend well beyond just the improvement in short-term economic return. Potential reduction in the development of insecticide resistance has considerable long-term economic implications. Furthermore, the low input program requires fewer applications of insecticides that are highly toxic to mammals: acute oral $\mathrm{LD}_{50}$ for methomyl $=17 \mathrm{mg} \cdot \mathrm{kg}^{-1}$, while methamidophos $=20 \mathrm{mg} \cdot \mathrm{kg}^{-1}$. The other insecticides have acute oral $\mathrm{LD}_{50}$ values $>3000 \mathrm{mg} \cdot \mathrm{kg}^{-1}$. B. thuringiensis has proven so nontoxic that no $\mathrm{LD}_{50}$ values have been established for mammals. In regions where resistance has not become severe, or during times when leafminers are not a critical pest, methamidophos can be omitted from the rotation. Therefore, the potential hazards to applicators, harvesters, and consumers would be further reduced.

The recent development of a field-based technique for rapid monitoring of resistance levels in both L. trifolii (Haynes et al., 1986; Sanderson et al., 1989) and S. exigua (unpublished data) offers the capability of determining whether or not the insecticide will provide a useful level of pest suppression in advance of application. Implementation of this technique will help to reduce the number of unnecessary and ineffective applications with the attendant reductions in human health concerns and environmental contamination.

\section{Literature Cited}

Baker, T. C., R.T. Staten, and H.M. Flint. 1989. Use of pink bollworm pheromone in the southwestern United States. In: R. Ridgeway, R. Silverstein, and M. Intscoe (eds.). Practical applications of pheromones and other attractants. Marcel Dekker, New York. (In press. )

California Celery Research Advisory Board. 1986. Economic impact report: The leafminer on California celery: Calif. Celery Res. Advisory Board, Dinuba.
Getzin, L.W. 1960. Selective insecticides for vegetable leafminer control and parasite survival. J. Econ. Entomol. 53:872-875.

Georghious, G.P. 1986. The magnitude of the resistance problem. Pesticide resistance: strategies and tactics for management. National Academy Press, NAS, Washington, D.C. p. 14-44.

Haynes, K. F., M.P. Parella, J.T. Trumble, and T.A. Miller. 1986. Monitoring insecticide resistance with yellow sticky cards. Cal if. Agr. 40: 1112.

Hills, O.A. and E.A. Taylor. 1951. Parasitization of dipterous leafminers in cantaloupes and lettuce in Salt River Valley, Arizona. J. Econ. Entomol. 44:759-762.

Johnson, H. B., P.G. Rowlands, and I.P. Ting. 1979. Tritium and carbon14 double isotope porometer for simultaneous measurements of transpiration and photosynthesis. Photosynthetica 13:409-418.

Johnson, M. W., E.R. Oatman, and J.A. Wyman. 1980. Effects of insecticides on populations of the vegetable leafminer and associated parasites on summer pole tomatoes. J. Econ. Entomol. 73:61-66.

Johnston, M. W., S.C. Welter, N.C. Toscano, I.P. Ting, and J.T. Trumble. 1983. Reduction of tomato leaflet photosynthesis rates by mining activity of Liriomyza sativae (Diptera: Agromyzidae). J. Econ. Entomol. 76: 10611063.

Keil, C.B. and M.P. Parrella. 1983. Liriomyza trifolii on chrysanthemums and celery: Managing an insecticide resistant population. Proc. Annu. Ind. Conf. on the Leafminer 3:162-167.

Lange, W. H., G.G. Agosta, K.S. Gob, and J.S. Kishiyama. 1980. Field effects of insecticides on chrysanthemum leafminer and a primary parasitoid, Chrysocharis ainsliei (Crawford), on artichokes in California. Environ. Entomol. 9:561-562.

Leibee, G.L. 1981. Insecticidal control of Liriomyza spp. on vegetables. Proc. IFAS-Industry Conf. on Biology and Control of Liriomyza Leafminers. 2:216-220.

Letourneau, D.K. 1987. The enemies hypothesis: Tritrophic interactions and vegetational diversity in tropical agroecosystems. Ecology 68:16161622.

Moar, W.J. and J.T. Trumble. 1987. Toxicity, joint action, and mean time of mortality of Dipel 2X, avermectin b1, neem and thuringiensin against beet armyworms (Lepidoptera: Noctuidae). J. Econ. Entomol. 588-592.

Moar, W. J., W.L.A. Osbrink, and J.T. Trumble. 1986. Potentiation of Bacillus thuringiensis var. kurstaki with thuringiensin on beet armyworm (Lepidoptera: Noctuidae). J. Econ. Entomol. 79:1443-1446.

Matthews, G.A. 1979. Pesticide application methods. Longman, London.

National Research Council. 1986. Pesticide resistancc: Strategies and tactics for management. National Academy Press, NAS, Washington, D.C.

Natwick, E.T. and A. Durazo, HI. 1985. Polyester covers protect vegetable from whiteflies and virus disease. Calif. Agr. 39:21-22.

Oatman, E.R. and G.G. Kennedy. 1976. Methomyl-induced outbreak of Liriomyza sativae on tomato. J. Econ. Entomol. 69:667-668.

Poe, S. L., P.H. Everett, D.J. Schuster, and C.A. Musgrave. 1978. insecticidal effects on Liriomyza sativae larvae and their parasites on tomato. J. Georgia Entomol. Soc. 13:322-324.

Pohronezny, K., V.H. Waddill, W.M. Stall, and W. Dankers. 1978. Integrated control of the vegetable leafminer (Liriomyza sativae Blanchard) during the 1977-78 tomato season in Dade County, Florida. Proc. Fla. State Hort. Soc. 91:264-267.

Poincelot, R.P. 1986. Toward a more sustainable agriculture. AW, Westport, Corm.

Power, A.G. 1988. Integrating control strategies for effective pest management. New York's Food and Life Sci. Quart. 17:7-9.

Reed, A.D. and L.A. Horel. 1979. Sample costs to produce crops. Univ. Calif. Coop. Ext. Lflt. 2360.

Sanderson, J. P., M.P. Parrella, and J.T. Trumble, 1989. Monitoring insecticide resistance in Liriomyza trifolii (Diptera: Agromyzidac) with yellow sticky cards. J. Econ. Entomol. 82: 1011-1018.

Trumble, J.T. 1981. Liriomyza trifolii could become a problem on celery. Calif. Agr. 35(9-10):30-31.

Trumble, J.T. 1985. Integrated pest management of Liriomyza trijolii: Influence of avermectin, cyromazine, and methomyl on leafminer ecology in celery. Agr. Ecosyst. Environ. 12: 181-188.

Trumble, J. T., W.J. Moar, J.R. Babu, and R. Dybas. 1987. Laboratory bioassays of the acute and antifeedant effects of avermectin $b_{1}$ and $a$ related analogue on Spodoptera exigua (Hübner). J. Agr. Entomol. 4:2128 .

Trumble, J.T. and H. Nakakihara. 1983. Occurrence, parasitization and sampling of Liriomyza specics (Diptera: Agromyzidac) infesting celery in California. Environ. Entomol. 12:810-814.

Trumble, J.T. and C.F. Quiros. 1988. Antixenotic and antibiotic resistance in Apium species to Liriomyza trifolii (Diptem: Agromyzidac). J. Econ. Entomol. 81:602-607.

Trumble, J. T., I.P. Ting, and L. Bates. 1985. Analysis of physiological, 
growth and yield responses of celery to Liriomyza trifolii. Entomol. Expt Appl. 38:15-21.

Trumble, J.T. and N.C. Toscano. 1983. Impact of methamidophos and methomyl on population of Liriomyza species (Diptera: Agromyzidae) and associated parasites in celery. Can. Entomol. 115:1415-1420.

Wene, G.P. 1955. Effect of some organic insecticides on the population levels of the serpentine leafminer and its parasites. J. Econ. Entomol.
48:596-597.

Zehnder, G.W. and J.T. Trumble. 1984. Host selection of Liriomyza species (Diptera: Agromyzidae) and associated parasites in adjacent plantings of tomato and celery. Environ. Entomol. 13:492-496.

Zehnder, G.W. and J.T. Trumble. 1985. Sequential sampling plans with fixed levels of precision for Liriomyza species (Diptera: Agromyzidac) in fresh market tomatoes. J. Econ. Entomol. 789:138-142.

\title{
Minimizing Pesticide Use in a Vegetable Management System
}

\author{
Christine Taylor Stephens \\ Department of Botany and Plant Pathology, Michigan State University, East Lansing, MI 48824
}

This nation is moving from an era of heavy dependency upon routine pesticide sprays to an age when more attention will be given to precision-timed application of fungicides and to implementation of alternative strategies to control plant pathogens. For more than a decade, terminology such as biological control, soil suppressiveness, hypovirulence, integrated pest management, and genetic engineering has been associated with research conducted in the discipline of plant pathology. Some of these disease control strategies are finally coming on line; others are still under development. Today, more than ever before, the alternative strategies are being taken seriously.

There are several reasons for this change. The first is concern for the environment. Newspapers are full of articles on toxic waste sites, increased rates of cancer in neighborhoods with contaminated soils, and linkages between pesticides and cancer. Concern by the American public has prompted new restrictive legislation to deal with chemical waste products. Past mishandling of chemical waste products continues to haunt us and slows present and future pesticide development and use.

Second, alternative control strategies are looking attractive because we are losing many of our important broad-spectrum fungicides. Recall the rumors circulating several years ago that $50 \%$ to $60 \%$ of the currently registered fungicides would be taken off the market within 5 years. These predictions were perceived as gross exaggerations not to be taken seriously. A review of the cancellations occurring over the past 2 years shows that the predictions may be uncomfortably close to reality.

In addition to cancellations, another concern related to fungicide use is that many new fungicides are specific for certain groups of plant pathogens. In general, they are more effective than broadspectrum fungicides on the few plant pathogens they control, but totally ineffective on non-target fungi. Bayleton is a representative example of these new materials. It is highly active against rust and powdery mildew fungi. While Bayleton is an excellent material for controlling powdery mildew on cucurbits, it is ineffective against the other leaf-spotting and fruit-rotting organisms that commonly affect this crop. Bayleton and other materials like it should not be considered as replacements for more traditional broad-spectrum materials, but rather as effective additions to the arsenal of chemical weapons.

The issue of farm profitability may also help explain renewed interest in alternative strategies. Profit margins are not as large as they were 10 years ago for most vegetable crops. Growers have discovered that use of a more integrated approach to controlling plant pests, rather than a routine 7-day pesticide spray schedule, may reduce costs and increase profit margins.

The first objective of this paper is to present several strategies researched over the past few decades that have made the transition from theory to application and are now being used on the farm. Second, several new and. conceptually different strategies in pest control will be presented. These strategies represent ideas and thoughts that are just now being researched at a basic level in the laboratory and may affect the farm in 10 to 15 years.

\section{Biocontrol agents}

Biological control of plant pathogens accomplished through traditional host plant resistance and cultural practices has been working for decades and continues to be the predominant disease control strategy. Biological control accomplished through introduction or encouragement of microorganisms antagonistic to plant pathogens has been slower to develop (Cook, 1981). Much progress has been achieved on the identification of antagonistic microorganisms that may be used as biocontrol agents. However, it is far easier to observe microbial antagonists in a petri plate than to make the organisms work as biocontrol agents in field situations. Research leading to a hypothesis as to how these organisms might function has helped identify the necessary desirable attributes of a biocontrol agent. First, an organism adapted to the environment of the pathogen has the best chance to control the disease successfully (Baker and Scher, 1987). For example, a nonpathogenic species of Pythium has been found that will colonize the sporangia of (and thereby suppress) a pathogenic species of Pythium that incites cucumber damping-off (Lifshitz et al., 1984). The use of a taxonomically related microorganism increases the chance of successful biological control as the organism is likely to occupy a similar ecological niche.

Second, to use biocontrol agents, we must be able to apply them economically and efficiently without losing effectiveness. The organism must be able to survive agricultural introduction in place of pesticides by methods such as seed application, overhead watering, and in-furrow applications (Baker and Scher, 1987). For example, research is currently being conducted on selecting desiccation-resistant fluorescent pseudomonades that can be introduced onto seeds. Other studies have focused on methods of preparing bacteria in such a way that survival is increased. A dry gum-talc formulation has been described that permits successful introduction of pseudomonades onto seeds (Suslow and Scroth, 1982).

Third, our biocontrol agent must be compatible with other methods of controlling pests (Baker and Scher, 1987). If pesticides must be used on the crop to protect it against other pathogens, the biocontrol agent needs to be compatible with those fungicides. Researchers have found a Trichoderma sp. isolate that is effective in suppressing Pythium damping-off in carnation. However, it was necessary to use benomyl in the system to control Rhizoctonia damping-off. Unfortunately, the biocontrol agent was sensitive to benomyl. The situation was resolved by the selection of a benomyltolerant strain of the biocontrol agent (Papavizas et al., 1982).

Another desirable characteristic of a successful biocontrol agent is the suppression of disease pathogens by a combination of several methods. Biocontrol agents suppress pathogens by such means as competition, antibiosis, and exploitation (Baker and Scher, 1987). Examples of antagonistic organisms using each method of control have been published. Competition for Fe has been shown to be one of the ways in which fluorescent pseudomonades suppress pathogenic soil microbes (Scher and Baker, 1980). These bacteria produce Reacquiring compounds called siderophores, which have a higher Febinding content than the siderophores of many fungi, making them 